\title{
Self-perceived Preparedness to Prescribe Antibiotics Among Swiss Medical Students: Results from a Cross-sectional Survey in four Swiss Universities in 2015.
}

Alice Ranzani ( $\square$ ali.ranz89@gmail.com )

Hopitaux Universitaires de Geneve https://orcid.org/0000-0002-4101-3524

Gaud Catho

Hopitaux Universitaires de Geneve

Céline Pulcini

Universite de Lorraine

Oliver J. Dyar

Karolinska Institutet

Benedikt D. Huttner

Hopitaux Universitaires de Geneve

Research article

Keywords: Medical students, antibiotic use, education, survey

Posted Date: August 17th, 2020

DOI: https://doi.org/10.21203/rs.3.rs-52901/v1

License: (c) (i) This work is licensed under a Creative Commons Attribution 4.0 International License. Read Full License 


\section{Abstract}

\section{Background}

Previous studies have highlighted that medical students do not feel well prepared to prescribe antimicrobials. The ESCMID Study Group for Antimicrobial stewardshiP (ESGAP) conducted a survey among European medical students to assess self-reported preparedness about prudent antibiotic use and the perceived lack of education. The aim of the present study was to specifically focus on the perceptions of Swiss medical students.

\section{Methods}

A cross-sectional web-based survey was conducted in 2015 by ESGAP involving sixth-year medical students from Switzerland. The survey investigated self-reported preparedness on diagnosis and treatment of infections, availability and perceived usefulness of different teaching methods and the perceived need for further education on antibiotic use. "Preparedness scores" were created by calculating the percentage of students who felt sufficiently prepared on each topic.

\section{Results}

We received responses from 137 medical students from 4 medical schools (Bern, Geneva, Lausanne and Zurich). The overall estimated response rate was $19 \%$. Overall, $62 \%$ of Swiss students reported needing more education on antibiotics or at least on their prudent use. Teaching methods perceived as more useful were discussion of clinical cases (80.2\%), clinical rotation in infectious diseases (77.0\%) and small group teaching $(75.0 \%)$, but the latter 2 were reported as unavailable for nearly half of the students $(36.5 \%$ and $47.5 \%$, respectively). Almost all of the students felt sufficiently prepared to recognize clinical signs of infection (99.3\%), to interpret inflammation markers (94.9\%) and to have sufficient knowledge of consequences of antibiotic misuse (95.5\%). Less than half of them felt prepared to select the right empirical treatment without using guidelines (33.8\%), to identify the need for combination therapy (39.7\%) or to select the shortest adequate treatment duration (39.3\%).

\section{Conclusions}

Most Swiss final year medical students feel they need more education on antibiotics. Some of the teaching methods perceived as more useful by students seem still insufficiently available in Swiss medical schools. Active and interprofessional teaching activities can be a first step towards more effective education on prudent antibiotic use.

\section{Background}

Antibiotic misuse is frequent and a key driver of antimicrobial resistance (AMR) [1, 2]. Educating future prescribers in the appropriate use of antimicrobials early during medical studies seems a key intervention for improving antibiotic use in the medium and long term [3-5]. Undergraduate curricula usually include 
learning objectives regarding the diagnosis and treatment of infections and increasingly highlight also the risk of misuse of antimicrobials and the global concern of increasing AMR $[3,6]$. Despite these efforts, previous studies have shown that medical students do not feel well prepared to appropriately prescribe antimicrobials at the end of their studies [7-10].

The ESCMID (European Society of Clinical Microbiology and Infectious Diseases) Study Group on Antimicrobial stewardshiP (ESGAP) conducted a cross-sectional web survey among final year medical students from 29 European countries, including Switzerland, in 2015, which has recently been published [11]. This Student-PREPARE survey investigated self-reported preparedness on different topics about prudent antibiotic use and the perceived lack of education, and compared the results among the participating countries. Although some differences emerged across countries, most European students expressed a need for more education on antibiotic use $[6,11,12]$. In this manuscript we present an in-depth subgroup-analysis of the Swiss results of the survey.

\section{Swiss medical school system}

The program of Swiss medical schools is regulated by Federal law [13]. It is composed of three years of Bachelor studies and three years of Master studies. In 2015 the full course could be conducted in 5 different universities (Basel, Bern, Lausanne, Geneva and Zurich), while Fribourg University offered only Bachelor studies. Nowadays, more universities offer Bachelor (Neuchâtel and University of Italian Switzerland) or Master studies (Fribourg, Lucerne, St. Gallen and University of Italian Switzerland).

During the Master studies, the majority of learning activities take place in hospitals. In the final year, students complete 10 months of clinical internships in different settings. At the end of the sixth year, students take the Swiss Federal Examination in Medicine, in order to continue their training as junior doctors at hospitals.

\section{Methods}

\section{Study design and participants}

This study was part of the ESGAP Student-PREPARE project, a cross-sectional multicentre web-based survey conducted in 2015 which aimed to assess final year medical students' self-reported preparedness on prudent antibiotic use, the results of which were published in 2018 [11]. Twenty-nine European countries [EU Member States together with the four European Free Trade Association countries (Iceland, Liechtenstein, Norway and Switzerland)] were involved in the study. In each country a local coordinator invited all medical students in their final year to participate, as previously described [11]. The survey was self-administered and was accessible on Survey-Monkey@ $@$ from January to December 2015. Here, we report the subset of data collected among Swiss medical students.

Questionnaire development 
The questionnaire was designed by international experts on antimicrobial stewardship and was informed by previous studies conducted among medical students $[7,10,14]$. The survey was composed of 47 items divided in 3 sections and was administered in English. The first section included questions on demographics. The second section assessed self-reported preparedness on 27 topics related to diagnosis and treatment of infections and prudent use of antibiotics; these questions were formulated using a 7-point Likert-type scale. The last section focused on availability and perceived usefulness of different teaching methods and the perceived need for further education.

\section{Statistical analyses}

The survey results were analysed using Microsoft Excel 2013 (Microsoft Corporation, Redmond, WA, USA). Categorical variables are presented as percentages.

Responses to questions on preparedness topics were merged in 2 categories $(1-3$, not sufficiently prepared; 4-7, at least sufficiently prepared). For each curriculum topic, a "preparedness score" was created by calculating the percentage of students who felt at least sufficiently prepared on each topic at medical school level. A national preparedness score for each topic was then calculated as the mean of the different medical school preparedness. A global preparedness score was calculated for each student as the percentage of topics on which the student felt at least sufficiently prepared. A medical school global preparedness score was then calculated as the mean of the student's preparedness score and finally a national preparedness score as the mean of the schools' preparedness scores. 
Table 1

Unavailability of teaching methods for antibiotic use among Swiss medical students.

\begin{tabular}{|c|c|c|c|c|c|}
\hline & Unavailak & ity, \% (n) & & & \\
\hline Teaching methods & $\mathrm{CH}$ & Berne & Geneva & Lausanne & Zurich \\
\hline & $N=137$ & $N=34$ & $N=22$ & $N=41$ & $N=40$ \\
\hline Lectures (with > 15 people) & $1.5 \%$ & $0.0 \%$ & $0.0 \%$ & $4.7 \%$ & $0.0 \%$ \\
\hline & $(2 / 137)$ & $(0 / 34)$ & $(0 / 22)$ & $(2 / 41)$ & $(0 / 40)$ \\
\hline Small group teaching (with $<15$ people) & $47.5 \%$ & $28.6 \%$ & $0.0 \%$ & $73.1 \%$ & $60.0 \%$ \\
\hline & $(65 / 137)$ & $(10 / 34)$ & $(0 / 22)$ & $(31 / 41)$ & $(24 / 40)$ \\
\hline Discussions of clinical cases and vignettes & $11.9 \%$ & $2.9 \%$ & $4.4 \%$ & $23.8 \%$ & $10.0 \%$ \\
\hline & $(16 / 137)$ & $(1 / 34)$ & $(1 / 22)$ & $(10 / 41)$ & $(4 / 40)$ \\
\hline Active learning assignments (e.g. article & $54.0 \%$ & $45.7 \%$ & $34.8 \%$ & $45.2 \%$ & $77.5 \%$ \\
\hline presentation) & $(74 / 137)$ & $(16 / 34)$ & $(8 / 22)$ & $(19 / 41)$ & $(31 / 40)$ \\
\hline E-learning & $55.5 \%$ & $37.1 \%$ & $43.5 \%$ & $54.8 \%$ & $75.0 \%$ \\
\hline & $(76 / 137)$ & $(13 / 34)$ & $(10 / 22)$ & $(23 / 41)$ & $(30 / 40)$ \\
\hline Role play or communication skills sessions & $69.3 \%$ & $57.1 \%$ & $43.5 \%$ & $71.4 \%$ & $87.5 \%$ \\
\hline therapy & $(95 / 137)$ & $(20 / 34)$ & $(10 / 22)$ & $(30 / 41)$ & $(35 / 40)$ \\
\hline Infectious diseases clinical placement (i.e. & $36.5 \%$ & $25.7 \%$ & $39.1 \%$ & $42.9 \%$ & $35.0 \%$ \\
\hline $\begin{array}{l}\text { diseases, involving patients) } \\
\text { dist }\end{array}$ & $(50 / 137)$ & $(9 / 34)$ & $(9 / 22)$ & $(18 / 41)$ & $(14 / 40)$ \\
\hline Microbiology clinical placement & $49.6 \%$ & $37.1 \%$ & $56.5 \%$ & $71.4 \%$ & $30.0 \%$ \\
\hline & $(68 / 137)$ & $(13 / 34)$ & $(13 / 22)$ & $(30 / 41)$ & $(12 / 40)$ \\
\hline Peer or near-peer teaching (i.e. teaching led & $52.6 \%$ & $42.9 \%$ & $34.9 \%$ & $47.6 \%$ & $72.5 \%$ \\
\hline doctors) & $(72 / 137)$ & $(15 / 34)$ & $(8 / 22)$ & $(20 / 41)$ & $(29 / 40)$ \\
\hline
\end{tabular}


Table 2

Self-reported preparedness on different curriculum topics

\begin{tabular}{|c|c|c|c|c|c|c|}
\hline \multirow[t]{2}{*}{ Curriculum topic } & \multicolumn{6}{|c|}{ Percentage of students who feel at least sufficiently prepared } \\
\hline & $\begin{array}{l}\text { Switzerland } \\
(n=137)\end{array}$ & $\begin{array}{l}\text { European } \\
\text { average } \\
(n= \\
7328)\end{array}$ & $\begin{array}{l}\text { University } \\
\text { of Berne } \\
(n=34)\end{array}$ & $\begin{array}{l}\text { University } \\
\text { of } \\
\text { Geneva } \\
(n=22)\end{array}$ & $\begin{array}{l}\text { University } \\
\text { of } \\
\text { Lausanne } \\
(n=41)\end{array}$ & $\begin{array}{l}\text { University } \\
\text { of Zurich } \\
(n=40)\end{array}$ \\
\hline $\begin{array}{l}\text { To recognise the } \\
\text { clinical signs of } \\
\text { infection }\end{array}$ & 99.3 & 95.7 & 100.0 & 100.0 & 100.0 & 97.4 \\
\hline $\begin{array}{l}\text { To assess the clinical } \\
\text { severity of infection } \\
\text { (e.g using criteria, } \\
\text { such as the septic } \\
\text { shock criteria) }\end{array}$ & 86.0 & 85.2 & 94.1 & 90.9 & 80.5 & 82.1 \\
\hline $\begin{array}{l}\text { To use point-of-care } \\
\text { tests (e.g. urine } \\
\text { dipstick, rapid } \\
\text { diagnostic tests for } \\
\text { streptococcal } \\
\text { pharyngitis) }\end{array}$ & 86.0 & 70.2 & 91.2 & 90.9 & 92.7 & 71.8 \\
\hline $\begin{array}{l}\text { To interpret } \\
\text { biochemical markers } \\
\text { of inflammation (e.g. } \\
\text { CRP) }\end{array}$ & 94.9 & 94.7 & 100.0 & 90.9 & 92.7 & 94.9 \\
\hline $\begin{array}{l}\text { To decide when it is } \\
\text { important to take } \\
\text { microbiological } \\
\text { samples before } \\
\text { starting antibiotic } \\
\text { therapy }\end{array}$ & 91.2 & 84.4 & 94.1 & 90.9 & 90.2 & 89.7 \\
\hline $\begin{array}{l}\text { To interpret basic } \\
\text { microbiological } \\
\text { investigations (e.g. } \\
\text { blood cultures, } \\
\text { antibiotic } \\
\text { susceptibility } \\
\text { reporting) }\end{array}$ & 86.8 & 86.4 & 85.3 & 95.5 & 90.2 & 79.5 \\
\hline $\begin{array}{l}\text { To identify clinical } \\
\text { situations when not } \\
\text { to prescribe an } \\
\text { antibiotic }\end{array}$ & 79.4 & 79.8 & 88.2 & 81.8 & 80.5 & 69.2 \\
\hline $\begin{array}{l}\text { To differentiate } \\
\text { between bacterial } \\
\text { colonisation and } \\
\text { infection (e.g. } \\
\text { asymptomatic } \\
\text { bacteriuria) }\end{array}$ & 80.9 & 73.6 & 76.5 & 72.7 & 85.4 & 84.6 \\
\hline
\end{tabular}




\begin{tabular}{|c|c|c|c|c|c|c|}
\hline \multirow[t]{2}{*}{ Curriculum topic } & \multicolumn{6}{|c|}{ Percentage of students who feel at least sufficiently prepared } \\
\hline & $\begin{array}{l}\text { Switzerland } \\
(n=137)\end{array}$ & $\begin{array}{l}\text { European } \\
\text { average } \\
(n= \\
7328)\end{array}$ & $\begin{array}{l}\text { University } \\
\text { of Berne } \\
(n=34)\end{array}$ & $\begin{array}{l}\text { University } \\
\text { of } \\
\text { Geneva } \\
(n=22)\end{array}$ & $\begin{array}{l}\text { University } \\
\text { of } \\
\text { Lausanne } \\
(n=41)\end{array}$ & $\begin{array}{l}\text { University } \\
\text { of Zurich } \\
(n=40)\end{array}$ \\
\hline $\begin{array}{l}\text { To differentiate } \\
\text { between bacterial and } \\
\text { viral upper respiratory } \\
\text { tract infections }\end{array}$ & 85.3 & 84.1 & 88.2 & 81.8 & 90.2 & 79.5 \\
\hline $\begin{array}{l}\text { To select initial } \\
\text { empirical therapy } \\
\text { based on the most } \\
\text { likely pathogen(s) } \\
\text { and antibiotic } \\
\text { resistance patterns, } \\
\text { without } \\
\text { using guidelines }\end{array}$ & 33.8 & 56.0 & 20.6 & 36.4 & 51.2 & 25.6 \\
\hline $\begin{array}{l}\text { To decide the urgency } \\
\text { of antibiotic } \\
\text { administration in } \\
\text { different situations } \\
\text { (e.g }<1 \text { hr for severe } \\
\text { sepsis, non-urgent for } \\
\text { chronic bone } \\
\text { infections) }\end{array}$ & 58.1 & 62.2 & 58.8 & 59.1 & 65.9 & 48.7 \\
\hline $\begin{array}{l}\text { To prescribe antibiotic } \\
\text { therapy according to } \\
\text { national/local } \\
\text { guidelines }\end{array}$ & 66.9 & 68.5 & 70.6 & 68.2 & 73.2 & 56.4 \\
\hline $\begin{array}{l}\text { To assess antibiotic } \\
\text { allergies (e.g. } \\
\text { differentiating } \\
\text { between anaphylaxis } \\
\text { and hypersensitivity) }\end{array}$ & 71.3 & 64.9 & 70.6 & 63.6 & 75.6 & 71.8 \\
\hline $\begin{array}{l}\text { To } \\
\text { identify indications } \\
\text { for combination } \\
\text { antibiotic therapy }\end{array}$ & 39.7 & 49.6 & 41.2 & 31.8 & 51.2 & 30.8 \\
\hline $\begin{array}{l}\text { To decide the shortest } \\
\text { possible adequate } \\
\text { duration of antibiotic } \\
\text { therapy for a specific } \\
\text { infection }\end{array}$ & 39.3 & 44.5 & 32.4 & 36.4 & 56.1 & 28.9 \\
\hline $\begin{array}{l}\text { To prescribe } \\
\text { using principles of } \\
\text { surgical antibiotic } \\
\text { prophylaxis }\end{array}$ & 33.3 & 51.4 & 32.4 & 27.3 & 41.5 & 28.9 \\
\hline
\end{tabular}




\begin{tabular}{|c|c|c|c|c|c|c|}
\hline \multirow[t]{2}{*}{ Curriculum topic } & \multicolumn{6}{|c|}{ Percentage of students who feel at least sufficiently prepared } \\
\hline & $\begin{array}{l}\text { Switzerland } \\
(n=137)\end{array}$ & $\begin{array}{l}\text { European } \\
\text { average } \\
(n= \\
7328)\end{array}$ & $\begin{array}{l}\text { University } \\
\text { of Berne } \\
(n=34)\end{array}$ & $\begin{array}{l}\text { University } \\
\text { of } \\
\text { Geneva } \\
(n=22)\end{array}$ & $\begin{array}{l}\text { University } \\
\text { of } \\
\text { Lausanne } \\
(n=41)\end{array}$ & $\begin{array}{l}\text { University } \\
\text { of Zurich } \\
(n=40)\end{array}$ \\
\hline $\begin{array}{l}\text { To review the need to } \\
\text { continue or change } \\
\text { antibiotic therapy } \\
\text { after } 48-72 \text { hours, } \\
\text { based on clinical } \\
\text { evolution and } \\
\text { laboratory results }\end{array}$ & 64.0 & 67.7 & 61.8 & 63.6 & 75.6 & 53.8 \\
\hline $\begin{array}{l}\text { To assess clinical } \\
\text { outcomes and } \\
\text { possible reasons for } \\
\text { failure of antibiotic } \\
\text { treatment }\end{array}$ & 62.5 & 68.3 & 64.7 & 54.5 & 68.3 & 59.0 \\
\hline $\begin{array}{l}\text { To decide when to } \\
\text { switch from } \\
\text { intravenous (IV) to } \\
\text { oral antibiotic therapy }\end{array}$ & 42.6 & 52.3 & 44.1 & 40.9 & 56.1 & 28.2 \\
\hline $\begin{array}{l}\text { To measure/audit } \\
\text { antibiotic use in a } \\
\text { clinical setting, and to } \\
\text { interpret the results of } \\
\text { such studies }\end{array}$ & 37.9 & 45.9 & 41.9 & 10.5 & 45.9 & 40.5 \\
\hline $\begin{array}{l}\text { To work within } \\
\text { the multi-disciplinary } \\
\text { team in managing } \\
\text { antibiotic use in } \\
\text { hospitals }\end{array}$ & 53.0 & 52.0 & 63.6 & 28.6 & 58.5 & 51.3 \\
\hline $\begin{array}{l}\text { To discuss antibiotic } \\
\text { use with patients who } \\
\text { are asking } \\
\text { for antibiotics, when } \\
\text { I feel they are not } \\
\text { necessary }\end{array}$ & 80.1 & 82.6 & 79.4 & 90.9 & 80.5 & 74.4 \\
\hline $\begin{array}{l}\text { To communicate with } \\
\text { senior doctors in } \\
\text { situations where I feel } \\
\text { antibiotics are not } \\
\text { necessary, but I feel I } \\
\text { am } \\
\text { being inappropriately } \\
\text { pressured into } \\
\text { prescribing antibiotics } \\
\text { by senior doctors }\end{array}$ & 40.7 & 43.9 & 47.1 & 31.8 & 37.5 & 43.6 \\
\hline
\end{tabular}




\begin{tabular}{|c|c|c|c|c|c|c|}
\hline \multirow[t]{2}{*}{ Curriculum topic } & \multicolumn{6}{|c|}{ Percentage of students who feel at least sufficiently prepared } \\
\hline & $\begin{array}{l}\text { Switzerland } \\
(n=137)\end{array}$ & $\begin{array}{l}\text { European } \\
\text { average } \\
(n= \\
7328)\end{array}$ & $\begin{array}{l}\text { University } \\
\text { of Berne } \\
(n=34)\end{array}$ & $\begin{array}{l}\text { University } \\
\text { of } \\
\text { Geneva } \\
(n=22)\end{array}$ & $\begin{array}{l}\text { University } \\
\text { of } \\
\text { Lausanne } \\
(n=41)\end{array}$ & $\begin{array}{l}\text { University } \\
\text { of Zurich } \\
(n=40)\end{array}$ \\
\hline $\begin{array}{l}\text { To use knowledge of } \\
\text { the common } \\
\text { mechanisms of } \\
\text { antibiotic resistance } \\
\text { in pathogens }\end{array}$ & 80.9 & 72.6 & 76.5 & 77.3 & 80.5 & 87.2 \\
\hline $\begin{array}{l}\text { To use knowledge } \\
\text { of the epidemiology } \\
\text { of bacterial } \\
\text { resistance, including } \\
\text { local/regional } \\
\text { variations }\end{array}$ & 62.5 & 57.4 & 64.7 & 45.5 & 65.9 & 66.7 \\
\hline $\begin{array}{l}\text { To practise effective } \\
\text { Infection control and } \\
\text { hygiene (to prevent } \\
\text { spread of bacteria) }\end{array}$ & 92.6 & 89.1 & 88.2 & 90.9 & 92.7 & 97.4 \\
\hline $\begin{array}{l}\text { To use knowledge } \\
\text { of the negative } \\
\text { consequences of } \\
\text { antibiotic use } \\
\text { (bacterial resistance, } \\
\text { toxic/adverse effects, } \\
\text { cost, Clostridium } \\
\text { difficile infections) }\end{array}$ & 95.5 & 88.5 & 97.0 & 95.5 & 90.0 & 100.0 \\
\hline
\end{tabular}

\section{Ethical approval}

The study was approved by the Ethics Committee of Nancy University Hospital, France. Participation was voluntary, anonymous and without compensation.

\section{Results}

\section{Participation}

We received responses from 137 medical students from 4 Swiss medical schools: Bern (Be) (n: 34; 24.8\%), Geneva (Ge) (n: 22; 16.1\%), Lausanne (La) (n: 41; 29.9\%) and Zurich (Zu) (n: 40; 29.2\%). The University of Basel did not participate in the survey because we were not able to identify a correspondent for administration of the survey. Among the contacted medical schools, the response rate for Switzerland was $19 \%$, similar to the median response rate across countries (20\%). The median age of the students was 25 years old (IQR 24.8-26.0) and 54.7\% (75/137) of them were female. 
Overall, $62 \%$ (80/130 participants who answered this section of the questionnaire) of Swiss medical students reported that they felt they needed more education on antibiotic use in order to be prepared for their future work as junior doctors. Of them, 31.8\% (41/130) felt they had enough training on general use of antibiotic treatments, but that they needed more training on their prudent use, while $30.2 \%(39 / 130)$ expressed the need for more education on both general and prudent use of antibiotics.

Similar to the other European countries, teaching methods perceived as more useful when available were discussion of clinical cases $(97 / 121,80.2 \%)$, clinical rotation in infectious diseases $(67 / 87,77 \%)$ and small group teaching sessions (54/72, $75.0 \%$ ); however, the latter 2 were reported unavailable for $36.5 \%$ (50/137) and $47.5 \%(65 / 137)$ of the Swiss students (figure 1$)$.

Compared to the European average [11] many teaching methods were more frequently reported as unavailable in Switzerland, such as small group teaching (47.5\% in Europe vs $18.7 \%$ in Switzerland), active learning assignments ( $54.0 \%$ vs $33.8 \%)$, peer-to-peer teaching ( $52.6 \%$ vs $38.3 \%)$, clinical rotations in infectious diseases (36.5\% vs $23.8 \%$ ) and microbiology ( $49.6 \%$ vs $37.3 \%)$ and role play sessions $(69.3 \%$ vs $57.5 \%$ ). Unavailability of teaching methods among the four Swiss Universities involved in the study are shown in more detail in table 1.

\section{Global preparedness score}

The global preparedness score for Switzerland was $67.9 \%$. This result was concordant with the median global preparedness score across Europe (71.2\%) [11].

\section{Preparedness in different curriculum topics}

Self-reported preparedness of Swiss students in the different curriculum topics is described in table 2. Almost all of the students felt sufficiently prepared to recognize clinical signs of infection (99.3\%), to interpret marker of inflammation (94.9\%), to recognize the right moment to perform microbiological tests (91.2\%), to practice infection control (92.6\%) and to have a good knowledge of negative consequences of antibiotic misuse (95.5\%). Similar score of preparedness were observed among the four different Universities who participated in the study for the topics referred to "diagnostic" skills, with the exception of preparedness for the use of point-of-care tests, which was lower in Zurich $(71.8 \%)$ when compared to the other schools (La 92.7\%, Be 91.2\% and Ge 90.9\%).

Conversely, lower preparedness rates emerged in the sections where "prescription" skills were investigated. More than half of the students $(66.9 \%)$ felt sufficiently prepared to prescribe an antimicrobial treatment according to guidelines (La: $73.2 \%$, Be: $70.6 \%$, Ge: $68.2 \%$ and $\mathrm{Zu}: 56.4 \%$ ), but this rate was lower when students were asked to prescribe without using guidelines (33.8\%); Lausanne was the only school where at least half of the students $(51.2 \%)$ reported that they felt sufficiently prepared for this task (Ge: $36.4 \%$, Zu: $25.6 \%$ and Be: $20.6 \%)$.

Less than half $(42.6 \%)$ of the students felt prepared to decide if the switch to an oral treatment was feasible, with the lowest score reported in Zurich (La: $56.1 \%$, Be: $44.1 \%$, Ge $40.9 \%$ and Zu: $28.2 \%$ ), and only 
$39.3 \%$ felt ready to decide the shortest adequate duration of a treatment (La: $56.1 \%$, Ge: $36.4 \%$, Be: $32.4 \%$ and $\mathrm{Zu}: 28.9 \%)$. Moreover, students felt largely not enough prepared (39.7\%) to identify the need for combination therapy (La: $51.2 \%$, Be: $41.2 \%$, Ge: $31.8 \%$ and $\mathrm{Zu}: 30.8 \%$ ) and to prescribe prophylaxis (Switzerland: $33.3 \%$, La: $41.5 \%$, Be: $32.4 \%$, Zu: $28.9 \%$ and Ge: $27.3 \%$ ).

Capacity to measure antibiotic use was reported lower in Geneva (10.5\%) than in the other schools (La: $45.9 \%$, Be: $41.9 \%$ and $\mathrm{Zu}: 40.5 \%$ ) and as well as managing antibiotic use in a multidisciplinary team (Be: $63.6 \%$, La: $58.5 \%$, Zu: $51.3 \%$ and Ge: $28.6 \%$ ).

\section{Discussion}

This study shows that, as their European colleagues, Swiss students do not feel sufficiently prepared on antibiotic prescribing and they feel they need more education. Although the preparedness scores of Swiss students largely overlap with the European results, some differences can be highlighted.

The proportion of Swiss students who felt prepared to prescribe a treatment without using guidelines was much lower than that reported across Europe and, looking in detail, this was reported by all the universities but Lausanne. On the other hand, the rate of students feeling prepared to select a treatment according to guidelines was similar to European average. A similar pattern had emerged for UK students, suggesting the hypothesis that large availability of local guidelines may be helpful, especially for young physicians, but could lead to the feeling of not being capable to prescribe a treatment independently [11]. As guidelines will never be able to cover all possible clinical situations that prescribers face in real life practice, educators should pay particular attention to help students developing the skill to judge the applicability of guidelines.

Preparedness on use of point-of-care test was higher for Swiss students, but, as well as prescribing according to guidelines, this was one of the topics with the greatest variation in preparedness among countries, related to different availability of resources and variability in national recommendations [11].

Swiss students reported high scores of preparedness in diagnostic issues, as had their European colleagues involved in the Student-PREPARE survey and in previous studies [9-11,15]. However, misdiagnosis is one of the main reasons for unnecessary antimicrobial prescriptions, as well as misinterpretation of clinical or microbiological data [2]. Therefore, this self-confidence might be at least partially biased by some lack of "real life" clinical practice experience and failure to appreciate the "swampy lowlands" of medical decision making with real patients that do not fit textbook descriptions [16].

In the Student-PREPARE survey, higher levels of preparedness were consistently reported in some countries. Possible explanations for these findings include a difference in the quality of education provided in different countries, but also cultural factors related to self-confidence and preparedness feeling $[6,11,17]$. Cultural differences between French speaking and German speaking regions in Switzerland have been pointed out as one of the factors influencing the disparities regarding use of antibiotics and rates of antimicrobial resistance among Swiss cantons [18-20]. Although we observed some differences in the preparedness for some topics and in the availability of teaching methods among universities, we did not 
observe a correlation in strengths and weaknesses when comparing French (Geneva and Lausanne) and German speaking faculties (Berne and Zurich).

Swiss students, as well as their colleagues from other countries and disciplines [11,21], stressed the importance of active methods of learning, as well as their inadequate availability. Infectious disease internships, whose effectiveness in improving knowledge and confidence in AMS principles has been shown in different studies, should be encouraged and made possible for every student [21-23].

As suggested by King et al., some of the skills where students report the lower preparedness, which involve more complex antimicrobial stewardship (AMS) strategies, could be more difficult to address with traditional teaching methods, leading to the need of frequent re-evaluation of both teaching contents and their delivery methods $[21,24]$. Only half of the Swiss students (as well as the Europeans) reported feeling prepared to work in a multidisciplinary team, suggesting the need to move towards interprofessional educational strategies $[21,25]$. Workshops where pharmacy and medical students collaborate dealing with clinical case simulations have been shown to help both in conveying AMS concepts and in highlighting the importance of interprofessional collaboration [25]. Promoting interaction among different health care professions, by inviting pharmacists, dentists, nurses and midwives to participate in lectures where AMS concepts are taught to medical students, could set up the basis for cooperation.

The validity of our results may be partially limited by the low response rate, but this was similar to response rates obtained across Europe and to those reported by previous similar studies $[8,10,11]$. Nevertheless, as previously published, the low response rate does not necessarily undermine the study's representativeness $[26,27]$. Due to the small number of respondents, differences in responses between the different universities should be interpreted with caution. A larger participation could help to better understand possible gaps in the education program, as well as differences among Swiss universities, in order to define targets that need to be improved. Furthermore, the responses are self-reported and therefore do not necessarily reflect the objective "real degree" of preparedness or real practices with patients.

Since 2015 Switzerland has adopted a national strategy on antibiotic resistance [28]. Improved education of medical students is currently not a core component of the strategy. In 2019 ESCMID published a set of generic competencies in antimicrobial prescribing and stewardship relevant to every independent prescriber. Educators could benefit from this list to guide the revision of curricula and teaching materials [29]. More active and interprofessional teaching activities seem like an essential step to guarantee that future physicians will use antibiotics more responsibly than the preceding generations.

\section{Conclusions}

Most Swiss final year medical students feel they need more education on antibiotics or at least on their prudent use. Some of the teaching methods perceived as more useful by students, such as discussion of clinical cases or infectious diseases clinical placement, seem still insufficiently available in most Swiss medical schools. Active and interprofessional teaching activities, involving pharmacists, nurses and other health professions, can be a first step towards more effective education on prudent antibiotic use.

Page 12/16 


\section{Abbreviations}

ESCMID (European Society of Clinical Microbiology and Infectious Diseases); ESCMID Study Group for Antimicrobial stewardshiP (ESGAP); antimicrobial resistance (AMR); Bern (Be); Geneva (Ge); Lausanne (La); Zurich (Zu); antimicrobial stewardship (AMS).

\section{Declarations}

\section{Ethics approval and consent to participate}

The study has received ethical approval from Comité de Réflexion Ethique Nancéien HospitaloUniversitaire, the ethical committee of Nancy University Hospital, France. Written informed consent was obtained from all the participants. Participation was voluntary, anonymous and without compensation.

\section{Consent for publication}

Not applicable.

\section{Availability of data and materials}

The datasets used and/or analysed during the current study are available from the corresponding author on reasonable request.

\section{Competing interests}

The authors declare that they have no competing interests.

\section{Funding}

No funding was received for the conduct of this study. Gaud Catho was partly supported by Fonds National Suisse (grant numbers 47240_167079 and 40AR40_180215).

\section{Authors' contributions}

$A R, G C$ and $B D H$ analysed and interpreted the data. $C P$ and OJD designed the original study. AR, GC and $\mathrm{BDH}$ drafted the manuscript. All authors read and approved the final manuscript.

\section{Acknowledgements}

We thank all the students who participated in the study and all the members of the ESGAP StudentPREPARE Working Group.

\section{References}

1. WHO Global. Action Plan on Antimicrobial Resistance. 2015. 
2. Pulcini C, Cua E, Lieutier F, Landraud L, Dellamonica P, Roger PM. Antibiotic misuse: a prospective clinical audit in a French university hospital. Eur J Clin Microbiol Infect Dis. 2007 Apr;26(4):277-80.

3. Pulcini C, Gyssens IC. How to educate prescribers in antimicrobial stewardship practices. Virulence. 2013 Feb 15;4(2):192-202.

4. Ohl CA, Luther VP. Health care provider education as a tool to enhance antibiotic stewardship practices. Infect Dis Clin North Am. 2014 Jun;28(2):177-93.

5. WHO competency framework for health workers' education and training on antimicrobial resistance. Geneva: World Health Organization; 2018 (WHO/HIS/HWF/AMR/2018.1). Licence: CC BY-NC-SA 3.0 IGO.

6. Dyar OJ, Lund M, Lindsjö C, Stålsby Lundborg C, Pulcini C, French-Swedish Student-PREPARE ESGAP working group. Preparedness to prescribe antibiotics responsibly: a comparison between final year medical students in France and Sweden. Eur J Clin Microbiol Infect Dis. 2019 Feb 15.

7. Abbo LM, Cosgrove SE, Pottinger PS, Pereyra M, Sinkowitz-Cochran R, Srinivasan A, et al. Medical students' perceptions and knowledge about antimicrobial stewardship: how are we educating our future prescribers? Clin Infect Dis. 2013 Sep;57(5):631-8.

8. Minen MT, Duquaine D, Marx MA, Weiss D. A survey of knowledge, attitudes, and beliefs of medical students concerning antimicrobial use and resistance. Microb Drug Resist. 2010 Dec;16(4):285-9.

9. Dyar OJ, Howard P, Nathwani D, Pulcini C. ESGAP (the ESCMID [European Society of Clinical Microbiology, Infectious Diseases] Study Group for Antibiotic Policies). Knowledge, attitudes, and beliefs of French medical students about antibiotic prescribing and resistance. Med Mal Infect. 2013 Oct;43(10):423-30.

10. Dyar OJ, Pulcini C, Howard P, Nathwani D, ESGAP (ESCMID Study Group for Antibiotic Policies). European medical students: a first multicentre study of knowledge, attitudes and perceptions of antibiotic prescribing and antibiotic resistance. J Antimicrob Chemother. 2014 Mar;69(3):842-6.

11. Dyar OJ, Nathwani D, Monnet DL, Gyssens IC, Stålsby Lundborg C, Pulcini C, et al. Do medical students feel prepared to prescribe antibiotics responsibly? Results from a cross-sectional survey in 29 European countries. J Antimicrob Chemother. 2018 Aug 1;73(8):2236-42.

12. Sánchez-Fabra D, Dyar OJ, Del Pozo JL, Amiguet JA, Colmenero J, de D, Fariñas MDC, et al. Perspective of Spanish medical students regarding undergraduate education in infectious diseases, bacterial resistance and antibiotic use. Enferm Infecc Microbiol Clin. 2019;37(1):25-30.

13. Loi fédérale sur les professions de la santé LPSan. https://www.gesbg.admin.ch/gesbg/fr/home.html Accessed 23.09.2019.

14. Pulcini C, Wencker F, Frimodt-Møller N, Kern WV, Nathwani D, Rodríguez-Baño J, et al. European survey on principles of prudent antibiotic prescribing teaching in undergraduate students. Clin Microbiol Infect. 2015 Apr;21(4):354-61.

15. Pulcini C, Williams F, Molinari N, Davey P, Nathwani D. Junior doctors' knowledge and perceptions of antibiotic resistance and prescribing: a survey in France and Scotland. Clin Microbiol Infect. 2011 Jan;17(1):80-7. 
16. Schon D. The Reflective Practitioner: How Professionals Think In Action. Routledge.; 1984.

17. Deschepper R, Grigoryan L, Lundborg CS, Hofstede G, Cohen J, Kelen GVD, et al. Are cultural dimensions relevant for explaining cross-national differences in antibiotic use in Europe? BMC Health Serv Res. 2008 Jun 6;8:123.

18. Olearo F, Albrich WC, Vernaz N, Harbarth S, Kronenberg A. Swiss Centre For Antibiotic Resistance Anresis. Staphylococcus aureus and methicillin resistance in Switzerland: regional differences and trends from 2004 to 2014. Swiss Med Wkly. 2016;146:w14339.

19. Filippini M, Masiero G, Moschetti K. Socioeconomic determinants of regional differences in outpatient antibiotic consumption: evidence from Switzerland. Health Policy. 2006 Aug 22;78(1):77-92.

20. Achermann R, Suter K, Kronenberg A, Gyger P, Mühlemann K, Zimmerli W, et al. Antibiotic use in adult outpatients in Switzerland in relation to regions, seasonality and point of care tests. Clin Microbiol Infect. 2011 Jun;17(6):855-61.

21. King ST, Hand J, Stover KR, Bland CM. Comment on: Do medical students feel prepared to prescribe antibiotics responsibly? Results from a cross-sectional survey in 29 European countries. J Antimicrob Chemother. 2019 Jan;74(1)(1):276-7.

22. Justo JA, Gauthier TP, Scheetz MH, Chahine EB, Bookstaver PB, Gallagher JC, et al. Knowledge and attitudes of doctor of pharmacy students regarding the appropriate use of antimicrobials. Clin Infect Dis. 2014 Oct 15;59 Suppl 3:S162-169.

23. Stover KR, King ST, Barber KE. Impact of an infectious diseases advanced pharmacy practice experience on student knowledge. Curr Pharm Teach Learn. 2018;10(8):1022-5.

24. Stevens CD. Repeal and Replace? A Note of Caution for Medical School Curriculum Reformers. Acad Med. 2018 Oct;93(10):1425-7.

25. MacDougall C, Schwartz BS, Kim L, Nanamori M, Shekarchian S, Chin-Hong PV. An Interprofessional Curriculum on Antimicrobial Stewardship Improves Knowledge and Attitudes Toward Appropriate Antimicrobial Use and Collaboration. Open Forum Infect Dis. 2017;4(1):ofw225.

26. Schouten B, Cobben F. Indicators for the representativeness of survey response. Surv Methodol. 2009;12(13).

27. Cook C, Heath F, Thompson R. A Meta-Analysis of Response Rates in Web- or Internet-Based Surveys. Educ Psychol Meas. 2000 Dec;60(6)(1):821-36.

28. Strategy on Antibiotic Resistance Switzerland. Federal Council. https://www.bag.admin.ch/dam/bag/en/dokumente/mt/star/strategieberichtstar.pdf.download.pdf/strategy-on-antibiotic-resistance-en.pdf Accessed on 29 Oct 2019.

29. Dyar OJ, Beović B, Pulcini C, Tacconelli E, Hulscher M, Cookson B. ESCMID generic competencies working group. ESCMID generic competencies in antimicrobial prescribing and stewardship: towards a European consensus. Clin Microbiol Infect. 2019 Jan;25(1):13-9.

\section{Figures}




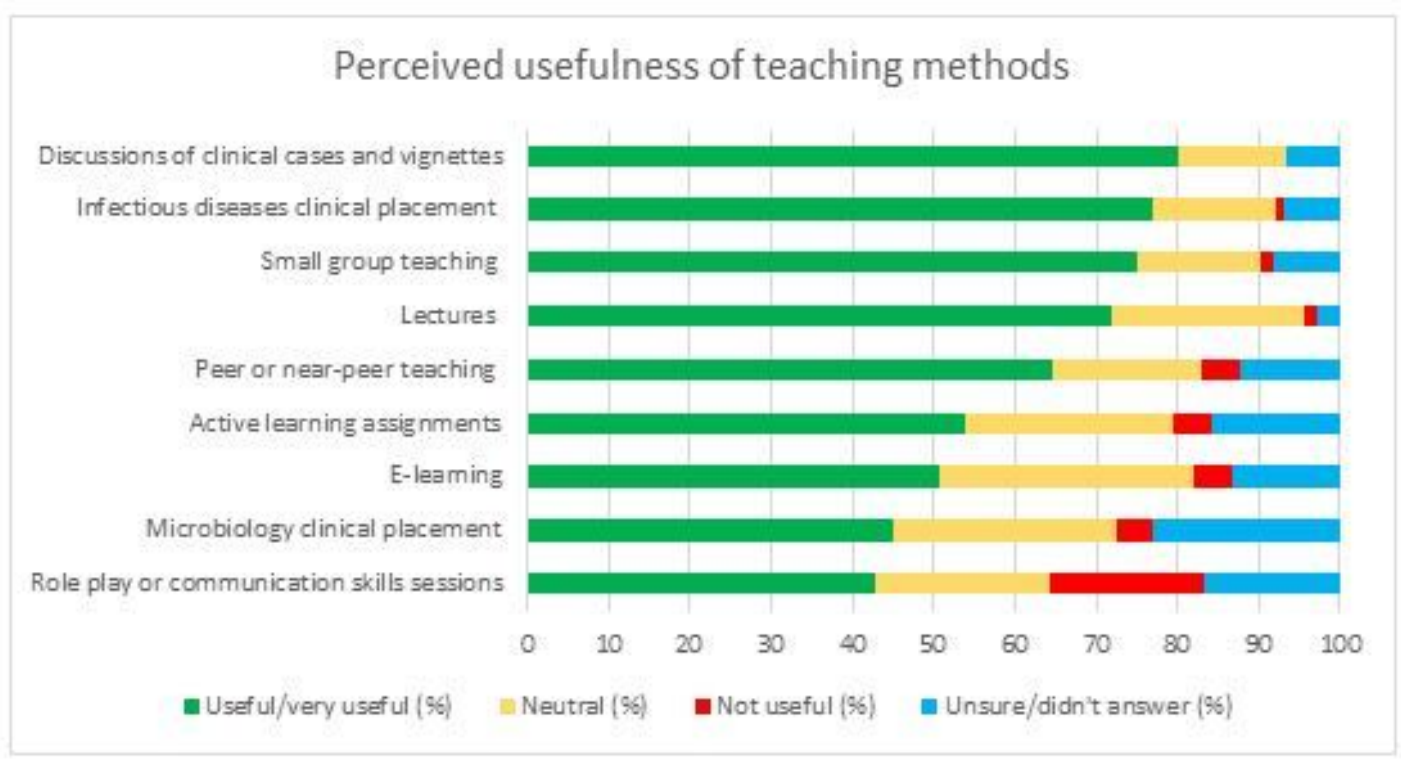

Figure 1

Perceived usefulness of teaching methods in Swiss Universities. 